\title{
O princípio da proporcionalidade no controle de constitucionalidade das leis sobre aborto*
}

\section{Verónica Undurraga}

Professora da Universidade Adolfo Ibáñez (Chile). Doutora em Direito pela Universidade do Chile e mestre em Direito pela Universidade de Columbia.

Tradução de Cristina Telles ${ }^{1}$

Mestra em Direito Público pela UERJ.

\section{Resumo}

Os tribunais têm se tornado cada vez mais conscientes da necessidade de adotarem uma abordagem principiológica para a resolução de conflitos constitucionais, exercida por meio de um juízo de ponderação. Conforme os julgamentos sobre aborto pelas cortes constitucionais vão tendo seu perfil alterado, novos marcos e referenciais para a fundamentação das decisões judiciais vão sendo testados. O presente artigo examina a metodologia seguida para controle da constitucionalidade de leis sobre aborto, enfatizando a proporcionalidade como uma ferramenta analítica, introduzida pelo Tribunal Constitucional alemão em 1975 e refinada em julgamentos mais recentes na Europa e na América Latina, que permite às cortes superar o modelo abstrato e intuitivo que caracterizava as decisões sobre aborto no passado.

*A equipe da Publicum agradece à Penn Press, que publicou o artigo original no livro "Abortion Law in Transnational Perspective: Cases and Controversies", a gentil autorização para publicação desta tradução em português.

${ }^{1}$ Assessora de Ministro do Supremo Tribunal Federal. Advogada do BNDES licenciada. 
O princípio da proporcionalidade traz para a consideração judicial assuntos substantivos e dados empíricos frequentemente negligenciados nas ações sobre aborto, exigindo dos julgadores não apenas a demonstração da racionalidade [teórica] da criminalização para a proteção da vida do nascituro, mas também a avaliação (i) da efetiva idoneidade da medida, (ii) da viabilidade de meios alternativos de proteção ao nascituro e (iii) dos sacrifícios demandados das mulheres, em contraposição aos alegados benefícios gerados a outros direitos ou valores constitucionais. Empregando essa ferramenta analítica, os juízes examinam as leis sobre aborto com base em três testes: adequação, necessidade e proporcionalidade em sentido estrito.

O uso do princípio da proporcionalidade tem resultado no apoio a instrumentos estatais de regulação do aborto fora do Direito Penal. Na última parte deste artigo, explica-se como os tribunais aplicaram o princípio da proporcionalidade para reconciliar deveres positivos do Estado de proteção ao nascituro com deveres negativos de não interferência em direitos das mulheres.

\section{Palavras-chave}

Aborto, princípio da proporcionalidade

\section{Proportionality in the Constitutional Review of Abortion Law}

\section{Abstract}

Courts are increasingly becoming more sensitive to the need for principled approaches that resolve constitutional conflicts through a reasoned balance of rights. As the shape of constitutional abortion judgments shift, courts are trying different frameworks through which to articulate their reasoning. This article analyzes judicial methodology in constitutional abortion law, focusing on proportionality as a reasoned analytical framework, introduced by the German Constitutional Court in 1975 and refined in more recent European and Latin American judgements, that allows courts to move beyond the abstract, intuitive decision-making that characterized abortion judgments of the past.

Proportionality brings into consideration substantive issues and empirical data too often neglected in abortion law adjudication, requiring judges to assess not merely the rationale, but also (i) the effectiveness of criminalization in protecting unborn life, (ii) the availability of alternative measures of protection and (iii) to account for the sacrifice 
criminalization demands of women against its alleged benefits. Using this analytical method, judges assess laws according to the three key standards of suitability, necessity and strict proportionality.

Proportional analysis of constitutional questions usually results in support for approaches to abortion regulation outside of criminal law. In the final part of the article, the author explains how courts have used proportionality to reconcile positive duties to protect unborn life with negative duties to abstain from interfering with women's rights.

\section{Keywords}

Abortion, proportionality principle.

\section{Sumário}

1. Introdução; 2. Princípio e doutrina da proporcionalidade; 3. O princípio da proporcionalidade como ferramenta analítica do controle de constitucionalidade; 3.1. O exame de adequação; 3.2. 0 exame de necessidade; 3.3. O exame de proporcionalidade em sentido estrito; 3.3.1. Peso abstrato: direitos das mulheres e vida do nascituro; 3.3.2. Os relativos impactos positivos e negativos da criminalização; 3.3.3. Uma questão de certeza: uma avaliação realista dos impactos negativos e positivos da criminalização; 4. Reconciliando deveres negativos e positivos; 5 . Conclusão.

\section{Introdução}

As decisões judiciais sobre aborto apresentam, com frequência, duas características marcantes. A primeira delas é a postura categórica que os tribunais tendem a adotar ao tomá-las, baseando-as em princípios morais e jurídicos abstratos, que dificilmente refletem as experiências das mulheres. A segunda característica, por sua vez, consiste na assunção, raramente justificada, de premissas intuitivas, especialmente duas delas: (i) a de efetividade da criminalização do aborto como medida de proteção à vida do nascituro e (ii) estereótipos de gênero variados, que subestimam os efeitos da penalização na vida das mulheres. Em que pesem essas características marcantes, os tribunais têm se tornado cada vez mais conscientes da necessidade de seguirem uma abordagem distinta quanto ao tema; menos categórica, que identifique os diferentes interesses envolvidos e busque solucionar o conflito entre eles mediante uma ponderação razoável. Nesse sentido, de mudança no perfil das decisões judiciais sobre aborto, as cortes têm procurado encontrar 
e testar novos marcos jurídicos para embasar seus julgamentos. Neste artigo, explorarei o princípio da proporcionalidade como uma metodologia que, quando aplicada pelos tribunais, tem resultado em um tratamento constitucional do aborto mais equilibrado, reduzindo a tendência de julgamentos que levem em conta apenas parte dos interesses envolvidos e que sejam insuficientemente fundamentados.

A proporcionalidade, como metodologia para resolução de conflitos constitucionais, requer dos juízes o enfrentamento, em etapas consecutivas, de determinadas questões, incentivando-os a refletir sobre assuntos muitas vezes negligenciados nos processos sobre aborto. A proporcionalidade demanda, por exemplo, que não apenas se qualifique a proteção da vida do nascituro como um dever constitucional ou como um interesse juridicamente relevante, mas que se avalie, também, a efetividade da criminalização do aborto para assegurar tal proteção. Com o levantamento da efetividade como uma questão a ser examinada pelos tribunais, a proporcionalidade abre espaço para a consideração de dados empíricos relevantes, como as medidas que mais reduzem as taxas de aborto e os efeitos da criminalização na vida das mulheres. A análise da efetividade, em outras palavras, exige que os juízes levem em conta os efeitos negativos da criminalização do aborto e confrontem-nos com os benefícios atribuídos à medida, tendo, em consequência, que considerar medidas alternativas de proteção à vida do nascituro, que possam ser igualmente efetivas, infringindo, porém, de maneira menos intensa os demais interesses em jogo. O princípio da proporcionalidade obriga, assim, os julgadores a explicitarem os benefícios e os custos associados à proteção da vida do nascituro e a questionarem-se sobre a alocação desses custos, que, até hoje, têm sido suportados desproporcionalmente pelas mulheres, em evidente limitação aos seus direitos constitucionais. Quando essas considerações são incorporadas à análise judicial e se confere a elas a devida atenção, o resultado usual tem sido favorável a enfoques alternativos à regulação penal do aborto ${ }^{2}$.

Este artigo divide-se em três partes. Na primeira delas, descrevo um pressuposto fundamental da doutrina da proporcionalidade, a saber: a interpretação dos direitos como princípios, e não como regras. Faço uso da decisão constitucional alemã de 1975 sobre aborto - tida como paradigmática na matéria - para demonstrar como se deram as primeiras e mais rudimentares aplicações do princípio da proporcionalidade ancoradas no referido pressuposto fundamental. A decisão alemã de 1975 é utilizada, ademais, como

2 Verónica Undurraga, Aborto y Protección del que Está por Nacer en la Constitución Chilena, (Santiago: Legal Publishing Chile [Thomson Reuters], 2014).

Revista Publicum

Rio de Janeiro, Número 2, 2016, p. 15-44.

http://www.e-publicacoes.uerj.br/index.php/publicum

DOI: $10.12957 /$ publicum.2016.25160 
ponto de partida para explorar os desenvolvimentos na aplicação da proporcionalidade na jurisprudência contemporânea.

$\mathrm{Na}$ segunda parte do artigo, exponho como o princípio da proporcionalidade funciona como ferramenta analítica para moldar - ou, mesmo, disciplinar e racionalizar o controle de constitucionalidade. Explico os três standards ou subprincípios dessa doutrina - adequação, necessidade e proporcionalidade em sentido estrito - e destaco as questões substanciais que emergem de cada um deles. Fazendo referência à jurisprudência comparada contemporânea, demonstro como os tribunais constitucionais têm refinado, progressivamente, a aplicação da doutrina da proporcionalidade, o que os tem levado a respaldar reformas legislativas cada vez mais liberais em matéria de aborto.

$\mathrm{Na}$ terceira parte, trato de um aspecto especialmente desafiante da análise da proporcionalidade das normas constitucionais sobre aborto: como os tribunais têm conciliado deveres positivos de proteção à vida do nascituro com deveres negativos de abstenção ou não interferência estatal em direitos das mulheres.

\section{Princípio e doutrina da proporcionalidade}

A proporcionalidade pode ser compreendida como uma ferramenta analítica do controle de constitucionalidade. Ela pressupõe que o sistema jurídico seja um sistema coerente de valores e que a tarefa judicial seja alcançar uma interpretação harmonizadora dos valores em conflito ("concordância prática"). Esses valores incluem direitos, mas também outros interesses objetivos constitucionalmente protegidos.

No direito constitucional, as normas sobre direitos podem estruturar-se como regras ou como princípios; e esta é uma distinção que tem a particular consequência de definir se e como os direitos poderão ser ponderados, ou, em outras palavras, se e como poderão ser analisados à luz da proporcionalidade. Direitos com estrutura de regras são normas categóricas: cumprem-se ou não. $O$ direito de um preso a ser posto à disposição de um juiz nas 48 (quarenta e oito) horas posteriores à sua prisão é, por exemplo, um direito com estrutura de regra. Duas regras contraditórias não podem ter aplicação ao mesmo tempo em uma mesma situação. Um conflito entre duas regras só pode, portanto, ser resolvido estabelecendo-se uma exceção a uma das regras, ou declarando-se uma delas inválida ou sem eficácia ${ }^{3}$. As interpretações judiciais que concebem as normas de

${ }^{3}$ Robert Alexy, A Theory of Constitutional Rights, trad. Julian Rivers (Oxford: Oxford University Press, 2202), p. 49.

Revista Publicum

Rio de Janeiro, Número 2, 2016, p. 15-44.

http://www.e-publicacoes.uerj.br/index.php/publicum

DOI: 10.12957/publicum.2016.25160 
direitos constitucionais como mandados categóricos e absolutos (cada direito é absoluto dentro de um âmbito especificamente delimitado) assumem que as normas de direitos fundamentais têm estrutura de regra. Essas interpretações são incompatíveis com a aplicação da doutrina da proporcionalidade, em cujo núcleo encontra-se a ideia de buscar um equilíbrio entre princípios em colisão. A Corte Suprema de Justiça da Costa Rica, por exemplo, declarou a inconstitucionalidade de uma lei que permitia a fecundação in vitro argumentando que a perda de embriões durante o procedimento infringia o direito absoluto à vida dos seres humanos, existente desde o momento da concepção ${ }^{4}$. A abordagem categórica adotada pela Corte sobre o direito à vida impediu uma análise do caso baseada no princípio da proporcionalidade. No entanto, a maioria das normas sobre direitos constitucionais são mais bem compreendidas se consideradas princípios, ao invés de regras.

Robert Alexy define princípios como "normas que ordenam que algo seja realizado na maior medida possível, de acordo com as possibilidades fáticas e jurídicas"5. Por definição, os princípios não podem ser absolutos - são "mandados de otimização, caracterizados pelo fato de poderem ser cumpridos em diferentes graus ${ }^{\prime 6}$. Portanto, princípios em colisão não apenas são capazes de coexistir em um sistema jurídico, como também podem ser aplicados simultaneamente na resolução de dada situação. Não existe uma hierarquia abstrata ou absoluta entre princípios. Ao contrário, eles são ponderados diante do contexto de determinado caso judicial, pelo que se estabelece uma precedência condicionada de um princípio sobre o outro, de acordo com as circunstâncias particulares do caso $^{7}$. Desse modo, direitos como princípios se adequam bem à análise da proporcionalidade, que busca maximizar todos os direitos na melhor extensão possível. A aplicação da proporcionalidade torna possível tomar uma decisão clara em um caso e resolver a colisão entre princípios para o referido caso particular. Essa decisão específica é categórica e pode expressar-se, portanto, na forma de uma regra. A caracterização dos direitos como regras ou como princípios nos ajuda a entender o direito constitucional em matéria de aborto. Na paradigmática decisão de 1975 do Tribunal Federal Alemão, instouse aquela corte a decidir se uma lei que legalizava o aborto dentro das primeiras doze semanas da gravidez infringia o direito à vida do nascituro. De acordo com o Tribunal, o

${ }^{4}$ Corte Suprema de Justiça de Costa Rica, Sala Constitucional, 2000, Sentença n. 200002306.

${ }^{5}$ Robert Alexy, Op. cit., p. 47.

${ }^{6}$ Robert Alexy, Op. cit., p. 47-48.

7 Robert Alexy, Op. cit., p. 50-54.

Revista Publicum

Rio de Janeiro, Número 2, 2016, p. 15-44.

http://www.e-publicacoes.uerj.br/index.php/publicum

DOI: $10.12957 /$ publicum.2016.25160 
dever de proteger a vida pré-natal decorre do reconhecimento da dignidade do nascituro, inferida da expressão "a dignidade humana é inviolável", que consta no artigo 1으, parágrafo primeiro, da Constituição alemã (Lei Fundamental). A decisão identificou como interesse em colisão o direito da gestante ao livre desenvolvimento de sua personalidade, o qual também reputou vinculado à dignidade humana ${ }^{8}$.

A decisão alemã é muitas vezes vista como categórica, ou seja, trataria o mandado de proteção à vida como uma regra que nega qualquer reconhecimento ao direito da mulher à autodeterminação. Essa interpretação do julgamento alemão baseia-se na assertiva, nele presente, de que o Estado deve regular o aborto partindo da premissa de que existe "um dever de levar a gravidez ao término... A condenação do aborto deve estar claramente expressada na ordem jurídica" ${ }^{\prime \prime}$.

Sem embargo dessa ótica, entendo que o Tribunal alemão adotou, na decisão ora examinada, o princípio da proporcionalidade, ainda que o aplicando de maneira rudimentar. Na ocasião, a Corte expressamente afirmou seu compromisso com um “princípio de equilíbrio que preserve o máximo das posições constitucionalmente protegidas em conflito" 10 e descreveu sua tarefa como a busca desse "necessário equilíbrio", no qual "ambos os valores constitucionais [a vida e a autodeterminação] devem ser apreciados em sua relação com a dignidade humana, que constitui o centro do sistema de valores da Constituição"11.

A declaração do Tribunal privilegiando a vida daquele que está por nascer pode, portanto, ser interpretada como o estabelecimento de um "necessário equilíbrio" entre valores que competem entre si, mais do que como uma regra. A fundamentação exposta pela Corte ampara essa interpretação. Nela, explicita-se que, diante de uma gravidez normal - i.e., aquela em que as circunstâncias da gestação não impõem uma carga ou restrição grave às mulheres, mas apenas o ônus normal que toda gestante tem de enfrentar -, a balança inclina-se de forma decisiva em favor da proteção da vida do nascituro. O Tribunal asseverou, nesse sentido, que uma solução de compromisso que, ao mesmo tempo, garantisse a vida pré-natal e o direito à autodeterminação (i.e., a liberdade para abortar) simplesmente "não é possível, uma vez que a interrupção da gravidez

\footnotetext{
8 Bundesverfassungsgericht [Tribunal Constitucional Federal], 25.02.1975, 39 BVerfGE 1, para. 151 [hereinafter 39 BVerfGE 1], traduzido em: Robert E. Jonas; John D. Gorby, "West German Abortion Decision: A Contrast to Roe v. Wade". John Marshall Journal of Practive and Procedure 9 (1976), p. 605-684.

${ }^{9} 39$ BVerfGE 1, trad. em: Robert E. Jonas; John D. Gorby, p. 644.

1039 BVerfGE 1, trad. em: Robert E. Jonas; John D. Gorby, p. 643.

1139 BVerfGE 1, trad. em: Robert E. Jonas; John D. Gorby, p. 643. 
sempre representará a destruição da vida do nascituro... [ao passo que a mulher pode, ainda assim, ter] muitas oportunidades para o desenvolvimento de [sua] personalidade"12. O Tribunal concluiu, então, que a "decisão... deve inclinar-se em favor da precedência da proteção da vida da criança en ventre sa mére em relação ao direito da mulher à autodeterminação"13.

Nos casos de "carga extraordinária", que leve a uma oneração da mulher superior à normalmente associada à gravidez, como ocorre quando há risco à vida ou à saúde da gestante $^{14}$, a ponderação dos valores em jogo se dá de modo distinto. Nessas circunstâncias, o Tribunal alemão considera que o Estado não pode exigir da mulher a continuidade da gestação. Nas palavras da própria Corte, a maternidade torna-se "inexigivel"15. O mesmo pode considerar-se em para outras situações, como, por exemplo, de grave má-formação fetal ou quando a gravidez é resultado de estupro; ou, ainda, quando a mulher enfrenta dificuldades econômicas e sociais extremas, que se caracterizem como "cargas extraordinárias para a mulher grávida que, do ponto de vista da inexigibilidade, são tão pesadas quanto" o perigo para sua vida ou saúde ${ }^{16}$. Em todos esses casos, explicou o Tribunal alemão, "outro interesse igualmente merecedor de proteção... impõe sua validade com tanta urgência que o Estado... não pode exigir da mulher grávida o dever de, diante de todas as circunstâncias, conferir precedência ao direito do nascituro" ${ }^{17}$.

Segundo a leitura aqui defendida da decisão em apreço, conclui-se que o Tribunal alemão tratou o valor da vida do nascituro e os direitos das mulheres - à vida, à saúde, mas também à autodeterminação - como princípios. Esses são valores e direitos que coexistem; que admitem graus distintos de proteção; e que são interpretados a partir da ideia de ponderação ou de equilíbrio de uns com os outros, de maneira a otimizar a tutela de todos eles. O fato de, em um caso particular, o equilíbrio alcançado mostrar-se decisivamente favorável ou mais protetivo de um valor do que de outro não anula o caráter "ponderativo" do juízo feito. Por essa razão é que afirmo que a metodologia da proporcionalidade - ainda que de uma forma rudimentar - fez parte da jurisprudência sobre aborto, desde essa antiga decisão alemã.

1239 BVerfGE 1, trad. em: Robert E. Jonas; John D. Gorby, p. 643.

1339 BVerfGE 1, trad. em: Robert E. Jonas; John D. Gorby, p. 643.

1439 BVerfGE 1, trad. em: Robert E. Jonas; John D. Gorby, p. 647-648.

1539 BVerfGE 1, trad. em: Robert E. Jonas; John D. Gorby, p. 648.

1639 BVerfGE 1, trad. em: Robert E. Jonas; John D. Gorby, p. 648.

${ }^{17} 39$ BVerfGE 1, trad. em: Robert E. Jonas; John D. Gorby, p. 648. 


\section{O princípio da proporcionalidade como uma ferramenta}

\section{analítica do controle de constitucionalidade}

Mesmo os tribunais que tratam os direitos como princípios, com frequência, têm dificuldade em não dar prioridade absoluta à vida, quando esta entra em colisão com outros direitos. De fato, considerar que a vida, diferentemente de outros direitos, não admite gradações em sua proteção é um argumento persuasivo, que pode levar os juízes a entenderem que há pouca, ou nenhuma, margem para a acomodação de outros valores na regulação do aborto. Essa postura pode ser constatada na decisão alemã de 1975: enquanto a vida do nascituro extingue-se mediante o aborto, a gravidez não impede todas as possibilidades de autodeterminação da mulher, motivo pelo qual se favorece a proibição penal do aborto.

A proporcionalidade como marco analítico, no entanto, rechaça esse tipo de juízo ponderativo tão básico. Mesmo que se repute a vida como o direito mais importante da ordem constitucional, parece razoável, senão necessário, perguntar-se se a criminalização do aborto efetivamente protege a vida do nascituro; se o fizer, em qual extensão; e, ainda, se esse mesmo objetivo não poderia ser igualmente ser obtido ou até obtido de melhor modo com medidas que afetassem menos os direitos das mulheres.

O princípio da proporcionalidade funciona como uma ferramenta analítica que dá forma e, talvez, até racionalize o controle judicial, mediante o estabelecimento de três exames consecutivos, que os tribunais devem aplicar ao avaliar a constitucionalidade de uma lei. São eles: o exame de adequação (ou idoneidade), o exame de necessidade e o exame de proporcionalidade em sentido estrito. A doutrina da proporcionalidade exige, assim, que, para uma lei ser declarada constitucional pelo tribunal competente, ela seja submetida aos três exames consecutivos acima mencionados e que seja aprovada em todos eles. Se a lei falhar em algum, não é preciso sequer continuar com os exames subsequentes; ela já terá que ser declarada inconstitucional.

O exame de adequação, em específico, exige que uma lei que restrinja um direito ou um valor constitucional seja conduzida ao atingimento de um objetivo constitucionalmente legítimo. O tribunal que a apreciar deve avaliar tanto a legitimidade do objetivo como a idoneidade dos meios que foram eleitos para alcançá-lo. Na análise das normas sobre aborto, o teste da adequação consiste, basicamente, em determinar se a criminalização é uma medida apta a proteger a vida do nascituro.

O exame da necessidade, a seu turno, requer que a lei que restrinja um direito constitucional seja necessária para atingir o objetivo constitucionalmente legítimo a que 
se destina, isto é, que não existam medidas igualmente efetivas e menos onerosas para se alcançar o objetivo visado pela lei. No controle de constitucionalidade das normas sobre aborto, o exame da necessidade leva ao questionamento sobre a criminalização constituir ou não a medida menos restritiva dos direitos da mulher, entre as demais eventualmente disponíveis que permitam obter a proteção da vida do nascituro.

O exame da proporcionalidade em sentido estrito, por fim, é um exercício bruto de ponderação, que busca determinar se os benefícios associados à lei restritiva de um direito constitucional compensam os sacrifícios por ela gerados. Aplicado às normas sobre aborto, esse terceiro teste exige dos tribunais saber se, mesmo tendo sido considerada uma medida adequada para proteger a vida do nascituro e a menos onerosa entre as alternativas disponíveis, a criminalização impõe um sacrifício justificável aos direitos das mulheres (i.e., menor do que as vantagens geradas).

A partir da análise da jurisprudência comparada contemporânea, espero demonstrar como os tribunais constitucionais têm refinado o exame da proporcionalidade e como a aplicação desse princípio tem resultado no favorecimento das regulações do aborto que se baseiam na prevenção, mais do que na repressão penal.

\subsection{O exame de adequação}

A primeira pergunta que um tribunal deve se fazer quando realiza o controle da constitucionalidade de uma lei penal sobre aborto é se tal lei se ampara em um objetivo constitucionalmente legítimo. Muitas vezes, a pergunta é omitida porque se assume, como um dado já certo e confiável, que a proteção à vida do nascituro é o objetivo buscado pela norma e que se trata de um objetivo legítimo. Sem embargo, crescentemente, os tribunais têm adotando um enfoque mais cuidadoso sobre o tema, examinando qual é, realmente, o objetivo da lei e sua legitimidade ou não.

Por exemplo, algumas decisões judiciais recentes que anularam proibições penais à interrupção da gestação de fetos anencefálicos examinaram a legitimidade do objetivo da lei perguntando como deve definir-se a vida a ser protegida ${ }^{18}$. O argumento comum de que a vida do nascituro é digna de proteção por fazer parte do processo de desenvolvimento humano e de que a proteção dessa vida tem por objetivo tornar possível o gozo dos direitos de uma pessoa no futuro não se sustenta no caso de fetos inviáveis. A legitimidade do objetivo da criminalização se põe, portanto, sob suspeita nessas situações.

${ }^{18}$ Veja-se um caso recente ocorrido no Brasil, conforme narrado por: Luís Roberto Barroso, "Bringing Abortion into Brazilian Public Debate: Legal Strategies for Anencephalic Pregnancy", em: Rebecca J. Cook, et. al., Abortion Law in Transnational Perspective: Cases and Controversies. 
Em outros casos, o texto da lei pode revelar que a criminalização não tem como único ou principal objetivo a proteção da vida do nascituro. Frequentemente, o que se deseja com a lei é, sobretudo, a afirmação de uma doutrina moral ou religiosa, visando a assegurar o agir virtuoso da mulher e dos profissionais de saúde. No Chile, por exemplo, as normas sobre aborto excluem da persecução criminal apenas os casos compatíveis com a doutrina católica do "duplo efeito", ou seja, quando a morte do feto não for o efeito esperado do tratamento médico dado à mulher para salvar sua própria vida (e.g., quimioterapia), mas possa advir como dano involuntário dessa medida ${ }^{19}$. Quando a concepção de "bem" que a lei adota se adscreve a uma religião em particular, mas o Estado, de acordo com a Constituição, deve ser neutro quanto às denominações religiosas, a legitimidade do objetivo legal torna-se discutível.

As leis sobre aborto que reforçam tradicionais papéis de gênero podem, também, ter a sua validade colocada em xeque sob a ótica da adequação. As normas que, por exemplo, punem mais severamente as mulheres do que as demais pessoas envolvidas na prática do aborto (inclusive os parceiros homens dessas mulheres) podem revelar um propósito de reiteração de estereótipos de gênero inaceitável. Do ponto de vista da proteção da vida do nascituro, a maior gravidade do tratamento dirigido à mulher certamente não faz sentido. Essas normas, portanto, sugerem que a criminalização do aborto destina-se, também, a reforçar um tradicional papel de mãe, como algo esperado socialmente das mulheres; daí se sancionar o não cumprimento desse suposto dever natural e especial de proteção ao feto, imposto às mulheres. Outro argumento em defesa da criminalização do aborto, questionável à luz da adequação, é a ideia paternalista de que a ameaça da pena e seu efeito dissuasivo previnem a mulher de sofrer as consequências de uma decisão pessoal errada. Ditas consequências incluíram o que se tem chamado de síndrome pós-aborto - apesar de as evidências em torno dos alegados danos psicológicos causados às mulheres serem amplamente criticadas ${ }^{20}$. Seja como for, nenhuma das normas acima referidas persegue [inteiramente] fins legítimos, pois se baseiam em estereótipos prejudiciais às mulheres, incompatíveis com o reconhecimento de sua dignidade e de sua igualdade como sujeitos de direito.

De todo modo, raramente, as leis sobre aborto deixam de atender, por completo, o requisito de vinculação a um fim legítimo. A maioria dos tribunais considera,

\footnotetext{
19 Antonio Bascuñán, "La Licitud del Aborto Consentido en el Derecho Chileno", Revista Derecho y Humanidades 10 (2004): 143-81, p. 156.

${ }^{20}$ Reva Siegel, "The Right's Reasons: Constitutional Conflict and the Spread of Woman Proctective Antiabortion Argument", Duke Law Journal 57, n. 6 (2008), p. 1641-1692.

Revista Publicum

Rio de Janeiro, Número 2, 2016, p. 15-44.

http://www.e-publicacoes.uerj.br/index.php/publicum

DOI: 10.12957/publicum.2016.25160
} 
corretamente, que tais leis, como outras que buscam proteger a vida humana e criar uma cultura de respeito pela dignidade, possuem objetivos legítimos. Em consequência, a pergunta mais relevante que o exame da adequação levanta, em matéria de aborto, diz respeito à idoneidade dos meios escolhidos para alcançar os fins legítimos perseguidos pela norma. Por isso, cada vez mais, o exame da adequação tem demandado evidências empíricas sobre a efetividade da lei, notadamente indicativos sobre a criminalização estar ou não associada a uma diminuição das taxas de aborto.

Os tribunais têm seguido esse padrão de análise e expressado que a criminalização do aborto "só se legítima quando for possível atribuir-se a ela, como requisito mínimo, a eficiência”21. E está comprovado que leis de aborto altamente restritivas não estão associadas a taxas menores de interrupção gestacional ${ }^{22}$. A título exemplificativo, é possível, primeiramente, levar em conta a taxa de aborto na África - de vinte e nove a cada mil mulheres em idade fértil - e na América Latina - de trinta e dois também a cada mil -, lembrando-se que, na maioria dos países de ambas as regiões, o aborto é, como regra geral, proibido. Em comparação, pode-se examinar a situação da Europa Ocidental, que apresenta uma taxa de aborto de doze a cada mil mulheres em idade fértil e onde, geralmente, admite-se legalmente a prática interruptiva da gestação. Vê-se, assim, que a proporção de mulheres que vivem sob leis liberais em matéria de aborto é inversamente associada à taxa de aborto existente nas diferentes regiões do mundo, o que talvez possa ser mais bem compreendido pelo fato de a quantidade de mulheres que gostariam de utilizar métodos anticoncepcionais modernos, mas não têm acesso a eles, ser menor nas regiões em que vigoram leis liberais sobre aborto do que naquelas dominadas por normas restritivas ${ }^{23}$.

\footnotetext{
${ }^{21}$ Tribunal Constitucional, 2010, Acórdão n. 75/2010, para. 11.4 .8 (Port.).

22 (i) Vanessa MacDonnel; Julia Hughes, "The German Abortion Decisions and the Protective Function in German and Canadian Constitutional Law". Osgoode Hall Law Journal 50.4 (2013), p. 999-1050.

23 Gilda Sedgh et. al., "Induced Abortion: Incidence and Trends Worlwilde from 1995 to 2008", Lancet 379, n. 9816 (2012): p. 625-632, doi: 10.1016/S0140-6736(11)61786-8 (acesso em 30.06.2013), p. 626; (ii) David A. Grimes et. al., "Unsafe Abortion: The Preventable Pandemic", Lancet 368, n. 9550 (2006): p. 1908-19, doi: 10.1016/S0140-6736(06)69481-6 (acesso em 31.01.2013); (iii) Alan Guttmacher Institute, "Sharing Responsability: Women, Society and Abortion Worldwilde", Abortion, Reports (1999), http://guttmacher.org/pubs/sharing.pdf; (iv) Alan Guttmacher Institute, "Facts on Induced Abortion Worldwilde", Abortion, Fact Sheets (out./2009), http://www.guttmacher.org/pubs/tb_LAW.html; (v) Cicely Marston; John Cleland, "Relationships Between Contraception and Abortion: A Review of the Evidence", International Family Planning Perspectives 29, n. 01 (2013): p. 06-13; (vi) Gilda Sedgh et. al., "Induced Abortion: Estimated Rates and Trends Worldwilde", Lancet 370, n. 9595 (2007): p. 1338-1345; (vii) Marge Berer, "National Laws and Unsafe Abortion: The Parameters of Change", Reproductive Health Matters 12 (2004), p: 01-08.
} 
De toda forma, o que precisa ser ressaltado é que o efeito dissuasivo da lei penal não pode ser presumido. O direito penal pode ser efetivo na prevenção de certos delitos, mas a sua efetividade depende, em grande medida, do tipo de conduta sancionada. A maioria das leis penais requer que as pessoas se abstenham de gerar dano a outros pela prática de atos que a maioria de nós não realizaria mesmo se fosse lícito fazê-lo. No caso do aborto, porém, a criminalização impõe às mulheres o cumprimento de obrigações positivas extremamente exigentes, relacionadas à gestação em si e à criação dos filhos; e o ato sancionado não é visto, muitas vezes, pelas mulheres que o praticam como causador de dano a terceiro, mas como uma conduta eminentemente pessoal. Esse é o ponto chave para se entender porque as leis penais têm sido tão pouco eficientes para prevenir a interrupção da gravidez. Os tribunais devem, ademais, confrontar o legislador com a existência de limites fáticos insuperáveis na utilização do direito penal para proteger a vida do nascituro. Para que as leis penais na matéria fossem efetivas, seria necessário que o Estado [i] tivesse conhecimento prévio da existência das gestações com risco de serem interrompidas e, assim, [ii] pudesse adotar as medidas preventivas necessárias nesses casos e [iii] conseguisse investigar e punir aqueles que escaparam à sua detecção e à suas políticas de prevenção. Nenhuma dessas três condições podem, no entanto, ser cumpridas em nossas sociedades. Se o aborto é criminalizado, as mulheres simplesmente escondem a gravidez e recorrem a serviços clandestinos, que são muito difíceis de serem perseguidos penalmente porque se realizam em segredo e com a cumplicidade de todos os envolvidos. Os métodos atuais utilizados para abortar, como a ingestão de determinados medicamentos, tornaram a interrupção da gravidez um acontecimento ainda mais privado. A não ser que se adotem medidas totalitárias, como as implementadas na Romênia durante o regime de Ceausescu nos anos 1980, em que todas as mulheres em idade fértil tiveram de submeter-se a exames ginecológicos mensais com o objetivo de identificar e monitorar possíveis gestações e assegurar-se de que elas seriam levadas adiante $^{24}$, a criminalização não funciona como uma medida apta a prevenir o aborto.

No passado, os tribunais tendiam a simplesmente aceitar a criminalização, sem atentar para sua efetividade como meio protetivo da vida do nascituro. Esse perfil decisório pode ser verificado, inclusive, no julgamento alemão de 1975 [acima comentado], que favoreceu a abordagem criminal do aborto, mesmo contra a evidência produzida pelo legislador à época, no sentido de que um regime preventivo poderia ser

${ }^{24}$ Ronald D. Bachman, ed., "Romania: A Country Study", Washington, D.C., GPO for the U.S. Library Congress, 1989, http://countrystudies.us/romania/37.htm (acesso em 31.02.2013). 
mais efetivo em salvar vidas. O tribunal argumentou que o dever constitucional existente seria de "proteção individual de cada vida singular e concreta" 25 , e que a adoção de um enfoque menos categórico no tema, que pudesse levar ao sacrifício de algum feto, seria uma concessão inaceitável. Há, porém, uma premissa subjacente - e equivocada - nessa afirmação da Corte, qual seja: a de que a criminalização, em si, não sacrifica vidas. Essa presunção, conforme assinalado, está errada, devido à ineficácia prática do sancionamento penal para prevenir abortos. Como ressaltado em voto dissidente do tribunal alemão, o argumento baseado no "sacrifício" funciona em ambas as direções; assim, mediante a criminalização [também] se sacrifica a vida, especificamente daqueles fetos que morrem na clandestinidade e que poderiam ter se salvado através das medidas alternativas propostas pelo legislador. Não importa, portanto, em termos de "vidas perdidas" que o aborto se realize mediante um regime legal autorizativo ou em um regime que o condene. É a eficácia global das medidas de proteção à vida adotadas pelos Estados que deve ser levada em conta no exercício de um controle de constitucionalidade que vise à proteção do nascituro. Sem embargo, em geral, os tribunais de todas as partes do mundo mostram-se reticentes em avaliar a efetividade da criminalização do aborto. $\mathrm{O}$ princípio da proporcionalidade, contudo, exige que eles o façam, analisando a adequação da lei aos fins por ela perseguidos.

$E$, de fato, foi somente a partir do momento em que começaram a se questionar sobre a efetividade das diferentes alternativas de regulação do aborto, que os tribunais começaram a apoiar regimes mais liberais, como, por exemplo, o de substituição da criminalização pelo aconselhamento. O Tribunal alemão foi um dos primeiros em que se verificou essa mudança de postura. Em 1993, a Corte reviu seu entendimento anterior e aceitou a constitucionalidade de uma lei que autorizava a mulher a optar pelo aborto nos meses iniciais da gestação, depois de um aconselhamento dissuasivo e um período de espera. O Tribunal admitiu que "ao menos na primeira etapa da gestação... a proteção efetiva da vida do nascituro só é possível com a colaboração da mãe"26. Argumentou, então, que "o segredo em relação ao nascituro, a vulnerabilidade e a dependência deste e seu vinculo único com a mãe parecem justificar a ideia de que as chances de o Estado protegê-lo são maiores se trabalhar em conjunto com a mãe" ${ }^{27}$. Em outras palavras, a Corte reconheceu que a criminalização não era capaz de proteger a vida do nascituro e

2539 BVerfGE 1, trad. em: Robert E. Jonas; John D. Gorby, p. 655.

${ }^{26}$ Bundesverfassungsgericht, 28.05.1993, 88 BVerfGE 203, para. 189.

2788 BVerfGE 1, 203, idem, para. 189. 
que o legislador tinha direito a promulgar uma lei alternativa, mais efetiva na regulação da matéria.

Em 2010, o Tribunal português seguiu o mesmo caminho e, aludindo à ineficácia da Direito Penal, confirmou a constitucionalidade de uma lei que descriminalizava o aborto nas dez primeiras semanas de gestação. O Tribunal afirmou que: "mais do que com os limites do direito penal, nos vemos confrontados, aqui, com os limites do Direito" ${ }^{28}$. No julgamento, o Tribunal reviu a adequação da criminalização, assentando a incapacidade da medida não apenas para diminuir as taxas de aborto, mas também para criar "um ambiente propício à decisão pela continuidade da gravidez"29. Mesmo se ignorarmos o fato de que raramente se proferem sentenças condenatórias por aborto, "quando, de maneira excepcional, [uma condenação] ocorre, a reação social é mais de desconforto do que de aplauso" 30 . Como o raciocínio desenvolvido pelo Tribunal sugere, a justificativa da criminalização amparada apenas na ideia de que a pena é um meio simbólico para expressar a reprovação social do aborto não é suficiente. De acordo com o Tribunal português, o questionamento sobre a efetividade da lei requer a demonstração de uma diminuição das taxas de aborto.

Em suma, o exame da adequação exige que qualquer limitação aos direitos das mulheres cumpra um propósito. Ou seja, a adequação demanda que as normas sobre aborto restritivas de direitos constitucionais ao menos atinjam algum objetivo legítimo, que justifique os ônus gerados. Uma lei que não cumpra com esse requisito, que imponha uma restrição a direitos sem beneficiar outros [direitos, valores ou interesses], é desproporcional e deve ser declarada inconstitucional.

\subsection{O exame de necessidade}

Se existe evidência de que a criminalização é idônea para alcançar um objetivo diminuindo as taxas de aborto ou criando uma cultura de respeito à vida humana - o requisito subsequente que se deve analisar consiste em saber se a criminalização configura meio necessário para alcançar o referido fim. Dito de outra forma, de acordo com a doutrina da proporcionalidade, os tribunais devem se perguntar se existem meios menos gravosos e igualmente ou mais efetivos do que a criminalização para alcançar os objetivos da lei. Se a resposta for positiva, a criminalização terá falhado no exame da necessidade e deverá ser declarada inconstitucional. A lei será, portanto, outra vez,

${ }^{28}$ Acórdão n. 75/2010, cf. nota 20 supra, para. 11.4.18.

${ }^{29}$ Acórdão n. 75/2010, cf. nota 20 supra, para. 11.4.18.

${ }^{30}$ Acórdão n. 75/2010, cf. nota 20 supra, para. 11.4.18. 
desproporcional, mas agora [não por inadequação, mas] por estar impondo ônus às mulheres e interferindo em seus direitos fundamentais desnecessariamente.

$\mathrm{Na}$ doutrina do direito penal, o exame da necessidade se expressa no conhecido princípio da ultima ratio: a ameaça de castigo penal deve ser o último recurso utilizado pelo legislador. A ideia subjacente a esse princípio é de que existe uma gama contínua de medidas protetivas, que vão desde as menos até as mais invasivas. O legislador deve optar pelas medidas que maximizem os interesses em conflito, isto é, que sejam menos invasivas e, ao mesmo tempo, suficientemente efetivas.

Em sua decisão de 1975, o Tribunal alemão reconheceu o princípio da ultima ratio, mas, como não questionou a efetividade da criminalização, acabou criando um pesado ônus probatório ao legislador, de demonstração de que uma lei liberalizante seria tão efetiva quanto o castigo penal para a proteção da vida do nascituro. O Tribunal já partiu da consideração de que "o sentido e a importância do valor jurídico que deve proteger-se [qual seja, a vida] exige" a aplicação da tutela penal ${ }^{31}$. Um dos votos vencidos do acórdão sobre aborto da Suprema Corte de Justiça da Nação (México), de 2008, desenvolveu raciocínio similar: "Não está à disposição da discricionariedade legislativa penalizar ou não condutas que atentem contra valores mínimos essenciais da sociedade. Quando o bem jurídico protegido é essencial, requer-se sua tutela no âmbito penal”32.

Esse raciocínio está errado por muitas razões. Em primeiro lugar, como argumentado no voto dissidente da decisão alemã de 1975, ao impor ao legislador o ônus de provar que a medida protetiva alternativa é tão efetiva quanto a criminalização, a opinião majoritária do Tribunal inverteu o princípio da ultima ratio. Em uma correta aplicação desse princípio, a criminalização é que deveria provar-se necessária, ao invés de ser assim presumida ${ }^{33}$. Em segundo lugar, não há, necessariamente, relação entre o caráter mais ou menos invasivo de uma medida e o grau de proteção que ela confere, isto é, sua efetividade. É provável, por exemplo, que a concessão de licença maternidade subsidiada e o acesso a creches públicas sejam medidas muito mais eficazes na prevenção do aborto do que a sanção penal.

Seguindo essa lógica, a Corte Constitucional da Colômbia aplicou o princípio da ultima ratio de modo bem distinto do adotado pelo tribunal alemão no caso acima citado, ao proferir sua paradigmática decisão de 2006, em que liberou a prática do aborto [ainda

\footnotetext{
3139 BVerfGE 1, cf. nota 07, para. 158.

32 Suprema Corte de Justiça da Nação, 2008, Ação de inconstitucionalidade n. 146/2007 e 147/2007. Voto dissidente proferido pelos juízes Aguirre, Azuela e Ortiz, p. 131-132.

3339 BVerfGE 1, cf. nota 07, para. 209-210; trad. em: Robert E. Jonas; John D. Gorby, p. 662-663. 
que em hipóteses específicas] ao examinar a quase absoluta proibição penal então vigente no país ${ }^{34}$. Em um caso anterior não relacionado à temática do aborto, o Tribunal assinalou que o princípio da proporcionalidade requer que se evite a criminalização quando o Estado tem à sua disposição meios menos restritivos de alcançar seus objetivos: "mostrase desproporcional que o legislador opte pelo meio mais invasivo da liberdade pessoal - o direito penal - quando conta com instrumentos menos lesivos a esses direitos constitucionais, para amparar os mesmos bens jurídicos"35. 0 mesmo princípio aplica-se ao contexto do aborto. E, assim, a Corte concluiu que o legislador pode recorrer ao direito penal somente quando existir uma "insuficiência de outros meios para garantir a proteção efetiva da vida do nascituro"36.

Em 2008, a Suprema Corte do México declarou a constitucionalidade da descriminalização do aborto nas primeiras doze semanas da gestação ${ }^{37}$. Essa decisão agregou um elemento interessante na aplicação do princípio da ultima ratio. A constitucionalidade da lei havia sido questionada por violar o direito à vida do nascituro. A opinião majoritária da Corte, no entanto, declarou que, a menos que a Constituição ou um tratado de direitos humanos obrigue o Estado a criminalizar o aborto, o legislador é livre para decidir qual é a medida mais apropriada para proteger a vida do nascituro ${ }^{38}$. 0 Tribunal também ressaltou que, se o legislador decidir criminalizar o aborto, deve respeitar os limites estabelecidos pelos direitos constitucionais das mulheres, para valerse do direito penal. A decisão mexicana é especialmente importante para o direito constitucional contemporâneo sobre aborto porque dissocia a discussão sobre o status da vida pré-natal da discussão sobre os meios de proteção devidos. Dessa forma, se rompe com a noção comum de que, sendo reconhecida ao feto a titularidade de direitos constitucionais, necessariamente haverá um dever constitucional de criminalização do aborto. Ao afastar-se uma concepção categórica, que encare o direito à vida como uma regra, e não como um princípio, permite-se que a proporcionalidade desempenhe papel bem mais proeminente no exame de constitucionalidade a ser feito.

Essa quebra jurisprudencial é cada vez mais comum no direito constitucional do aborto. Em 2010, o Tribunal português também deferiu ao legislador a opção de eleger as medidas protetivas do feto, rechaçando qualquer presunção em favor da maior efetividade da criminalização. A Corte expressamente afirmou que qualquer presunção de

\footnotetext{
34 Corte Constitucional, 10.05.2006, Sentença C-355/06, para. VI.5.

${ }^{35}$ Corte Constitucional, 2002, Sentença C-370/02, para. VI.22.

${ }^{36}$ Sentença C-355/06, cf. nota 33.

${ }^{37}$ Ação de inconstitucionalidade146/2007 e 147/2007, cf. nota 31, p. 189.

${ }^{38}$ Ação de inconstitucionalidade146/2007 e 147/2007, cf. nota 31, p. 189. 
legitimidade do uso do direito penal seria equivocada: "a sanção penal é o instrumento mais gravoso de intervenção... [e] não pode escapar a um escrutínio positivo... a eficiência do direito penal não pode ser automaticamente deduzida da ineficiência de outros meios" 39 .

Uma análise fundada no princípio da proporcionalidade exige, portanto, a avaliação comparativa das diversas medidas jurídicas de proteção, sendo vedada qualquer presunção no sentido de o meio mais invasivo ser, também, o mais efetivo. Ao invés disso, requer-se estudo e profundo entendimento das causas do aborto, bem como das boas práticas de prevenção existentes. Na aplicação do subprincípio da necessidade, os tribunais devem se guiar pela experiência dos países que tenham alcançado as mais baixas taxas de aborto, tendo as leis penais menos restritivas dos direitos das mulheres. $\mathrm{E}$, de fato, quando se consideram as evidências existentes, não se pode defender razoavelmente que as normais penais sejam necessárias, se o objetivo da lei é reduzir a incidência do aborto. Advogados e tribunais devem, assim, fazer uso desses crescentes estudos que demonstram que a intervenção estatal chave para reduzir a incidência do aborto se dá, por um lado, por programas efetivos e sustentáveis de educação e pelo acesso ao planejamento familiar, a fim de diminuir a quantidade de gestações não desejadas, e, por outro lado, pelo apoio econômico e social das mulheres que desejam continuar a gravidez e tornarem-se mães ${ }^{40}$.

Da mesma forma que a efetividade, a necessidade da criminalização não pode ser simplesmente assumida como um dado certo. À luz do princípio da proporcionalidade, o uso de medidas penais só se justifica como um último recurso, quando se demonstre que as medidas alternativas são insuficientes para proteger a vida do nascituro.

\subsection{O exame de proporcionalidade em sentido estrito}

Dada a falta de efetividade do direito penal e a existência de medidas menos gravosas, a maioria das leis que criminalizam o aborto durante a primeira fase da gestação provavelmente não passariam nos testes de adequação e de necessidade e, portanto, não precisariam sequer ser submetidas a um juízo de proporcionalidade em sentido estrito. Se um tribunal tiver, porém, a opinião de que a criminalização é, sim, idônea e necessária para proteger a vida do nascituro, então terá de avaliar a proporcionalidade em sentido estrito da medida. Esse exame busca determinar se os benefícios alcançados por uma lei

${ }^{39}$ Acórdão n. 75/2010, cf. nota 20, para. 11.4.8.

40 John Cleland et. Al., "Family Planning: The Unfinished Agenda”, Lancet 368, n. 9549 (2006): p. 1810-1827. 
que afete um direito constitucional são maiores do que as suas desvantagens. Trata-se de uma forma bruta ou crua de ponderação, em que se pergunta: os sacrifícios demandados por uma lei justificam-se em virtude do atingimento dos objetivos legítimos que ela persegue? Ao final, um conjunto de valores será favorecido em prejuízo de outro: os direitos das mulheres ou o direito à vida do nascituro.

Esse exame considera três fatores: (a) o "peso abstrato" ou a importância constitucional dos interesses independentemente das circunstâncias específicas do caso; (b) a intensidade dos impactos negativos e positivos sobre esses interesses; e (c) o grau de certeza em relação à materialização ou concretização desses impactos nas circunstâncias específicas do caso ${ }^{41}$.

\subsubsection{Peso abstrato: direitos das mulheres e vida do nascituro}

Os distintos sistemas constitucionais conferem importância também distinta aos diferentes interesses (direitos e valores) constitucionais. Nos Estados Unidos, por exemplo, a liberdade de expressão tem muito mais peso do que na maioria dos sistemas constitucionais do mundo. Na Alemanha, por sua vez, a dignidade humana é considerada o valor supremo do Estado, e isso se reflete na proibição expressa a qualquer tentativa de reforma do dispositivo constitucional que garante sua proteção. Alexy se refere a esse status outorgado aos diversos interesses e direitos constitucionais como seu "peso abstrato".

O peso abstrato do direito à vida do nascituro é considerado, muitas vezes, como o fator determinante nas controvérsias constitucionais sobre o aborto. Sem embargo, quer seja a vida do nascituro (i) um direito constitucional, (ii) um valor objetivo tutelado pela Constituição ou (iii) simplesmente um interesse legítimo que o Estado pode, mas não tem a obrigação de perseguir, o peso abstrato a ela conferido constitui um fator relevante, mas não necessariamente determinante da ponderação a ser feita à luz do princípio da proporcionalidade.

Ao se tratar o feto como um sujeito de direitos, por exemplo, o exame de proporcionalidade realiza-se entre interesses do mesmo tipo: direitos individuais fundamentais subjetivos (do feto e da mulher, respectivamente). Na Irlanda, o feto goza do direito constitucional à vida, e a lei permite o aborto somente para salvar a vida da mulher ${ }^{42}$. Em contraste, nos Estados Unidos, onde o aborto é admitido (ainda que com

\footnotetext{
${ }^{41}$ Robert Alexy, Theory, cf. nota 2, pós-escrito.

42 Bunreacht Na hÉireann [Constituição da Irlanda] 1937, art. 40.3.3. 
restrições) sem necessidade de invocarem-se causas ou motivos, a Suprema Corte negou expressamente ao feto a condição de sujeito de direitos e aceitou a proteção da vida prénatal somente na condição de interesse legítimo que o Estado pode proteger ${ }^{43}$.

Os tribunais da Alemanha, Espanha, Portugal e Eslováquia, entre outros europeus, tomaram posições intermediárias e declararam a vida do nascituro um valor constitucional (objetivo) que o Estado tem de proteger. O mesmo fez a Corte Constitucional da Colômbia, na América Latina. Quando a proteção da vida do nascituro é reputada um valor constitucional objetivo, e não um direito, os interesses em conflito diferem em espécie. Essa distinção não ensejou consequências significativas na análise rudimentar de proporcionalidade que o Tribunal alemão realizou em 1975, mas teve grande importância nos casos julgados pelos tribunais colombiano, português e eslovaco, que enfatizaram a prioridade prima facie dos direitos sobre os valores objetivos. Na linguagem da proporcionalidade, isso significa que os direitos têm um peso abstrato maior do que os interesses constitucionais que não se caracterizam como tal. Os tribunais constitucionais têm entendido que, como valor constitucional, a vida do nascituro não tem o mesmo grau de proteção outorgado à vida de pessoas já nascidas, considerada - esta sim - um direito constitucional subjetivo ${ }^{44}$. O Tribunal colombiano, por exemplo, declarou que "se é verdade que o ordenamento jurídico outorga proteção ao nascituro, não o faz no mesmo grau e intensidade que à pessoa humana" ${ }^{45}$. Dito de forma diferente, esses tribunais consideram que os direitos constitucionais têm maior peso do que os interesses constitucionais que não são direitos, pois possuem status diferente e superior no sistema constitucional. O Tribunal português adicionou outra consequência ao fato de a vida do nascituro ser um valor objetivo, e não um direito: "Enquanto um valor digno de tutela independentemente do interesse pessoal de alguém, a vida não está sujeita a uma lógica de proteção de 'tudo ou nada', resistente a gradações de 'mais ou menos'" ${ }^{46}$. A vida como valor permite um enfoque gradual de proteção. O peso abstrato da vida de um óvulo recentemente fecundado é menor do que o peso dado à vida de um feto que já tenha seis meses de existência.

Nada obstante as distinções acima indicadas, o peso abstrato não é determinado apenas pela caracterização de algo como direito ou como valor, mas também pela natureza do interesse específico que invoca. Ainda que a privacidade, a autonomia, a

${ }^{43}$ Roe v. Wade, 410 U.S. 113 (1973) (Suprema Corte norte-americana).

${ }^{44}$ Sentença C-355/06, cf. nota 33, para. VI.5; Acórdão n. 75/2010, cf. nota 20, para. 11.4.2; Ústavny Aúd [Corte Constitucional], 04.12.2007, PL. ÚS 12/02.

45 Sentença C-355/06, cf. nota 33, para. VI.5.

${ }^{46}$ Acórdão n. 75/2010, cf. nota 20, para. 11.4.11. 
liberdade e a igualdade sejam ideais muito valorizados em abstrato, têm seu peso frequentemente diminuído ou subestimado quando invocadas no contexto da vida das mulheres. A decisão do Tribunal Constitucional do Chile que invalidou a distribuição pública de anticoncepcionais de emergência [conhecidas popularmente como "pílulas do dia seguinte"], por reputar a medida ofensiva ao direito à vida do nascituro, não levou em conta, de maneira apropriada, direitos relevantes das mulheres, tendo feito alusão indireta a eles, apenas depois de já haver julgado a causa, declarando: "não escapa à consideração dessa Corte o impacto evidente que [a decisão]... produzirá em uma matéria que tem também implicações afetivas muito importantes para as pessoas, que são, sem dúvida, plenamente respeitáveis ${ }^{47 \prime}$. Em outras palavras, os direitos das mulheres foram reduzidos a meras "implicações afetivas muito importantes".

A recorrente diminuição do "peso abstrato" dos direitos das mulheres torna necessário que advogados e juízes façam-se expressamente a "pergunta sobre a mulher" ${ }^{\prime \prime 8}$. Isto é, que procurem determinar o peso relativo dos direitos em jogo a partir da perspectiva das mulheres, desafiando, assim, de alguma maneira, a ideia de que possa haver uma definição puramente abstrata e neutra em termos de gênero do peso dos diferentes direitos, valores e interesses constitucionais. Como podemos entender a decisão de continuar ou interromper uma gravidez como um exercício do direito à privacidade e à autonomia? Apesar de as acadêmicas feministas terem incorporado a expressão "direitos reprodutivos" ao vocabulário jurídico, a fim de designar e dar visibilidade ao conjunto de diretos humanos relacionados à vida reprodutiva das mulheres e dos homens, os tribunais têm se referido a eles, muitas vezes, como "novos direitos" - e, em consequência, têm-lhes outorgado status mais precário do que o reconhecido a direitos tradicionais, como liberdade e igualdade. Quando os direitos reprodutivos são tratados como "recém-chegados", acabam recebendo menor peso do que os direitos tradicionais, o que afeta a ponderação dos valores em conflito. Por essa razão, talvez seja necessário que a argumentação jurídica estabeleça uma conexão explícita entre os direitos reprodutivos e direitos tradicionais, mostrando como os primeiros são um exercício ou uma manifestação dos segundos, em um esforço para garantir que estes sejam significativos nas vidas reprodutivas de mulheres (e homens).

A dignidade humana é um desses direitos tradicionais. É considerada o fundamento de todos os direitos humanos e recebe peso abstrato significativo na maioria dos sistemas

\footnotetext{
47 Tribunal Constitucional, 18. 04.2008, Sentença Rol 740-07-CDS, para. 64.

48 Katharine T. Barlett, "Feminist Legal Method", Harvard Law Review 103, n. 4 (1990), p. 829-888. 
constitucionais. Apesar disso, a dignidade é um conceito controvertido que, muitas vezes, é utilizado de maneira diferente e contraditória nas disputas sobre aborto ${ }^{49}$. Os defensores da criminalização alegam a dignidade intrínseca à vida do nascituro e seu valor ínsito. Por outro lado, no direito constitucional comparado, cada vez com frequência maior, invoca-se a mesma dignidade como argumento para limitar o controle estatal sobre a vida reprodutiva das mulheres, afirmando-se que não se pode instrumentalizar as mulheres para a procriação e que a maternidade forçada viola a dignidade das mulheres como cidadãs plenas e iguais ${ }^{50}$. Esse argumento não apenas resgata a dignidade de sua vinculação exclusiva com a vida do nascituro, como expressamente a associa à autonomia, que constitui o sentido primário do princípio no direito de maneira geral. Como expressado pelo Tribunal português: "a carga axiológica do princípio da dignidade humana não recai exclusivamente do lado da vida intrauterina. Ela atua também em favor da posição jurídico-constitucional da mulher" ${ }^{51}$. Quando os tribunais começam a se referir à regulação do aborto em termos de dignidade da mulher, a mulher se torna visível como sujeito pleno de direito.

\subsubsection{Os relativos impactos positivos e negativos da criminalização}

A proporcionalidade em sentido estrito requer que se realize uma ponderação entre os efeitos concretos que determinada medida gera: no caso do aborto, há de sopesar-se, de um lado, o impacto positivo da criminalização sobre a proteção da vida do nascituro; e, de outro lado, o seu impacto negativo sobre os direitos e a vida das mulheres. Mesmo quando esteja claro que existem direitos ou valores importantes sendo tutelados, em tese, por uma norma criminalizadora, é impossível aferir a sua constitucionalidade, em um juízo ponderativo, sem que se verifique, antes, o quão intensos são, respectivamente, os impactos positivos e os negativos da criminalização sobre todos os direitos e valores em jogo.

Muitas decisões que consignam haver uma obrigação constitucional de criminalização do aborto baseiam-se na consideração de que o aborto leva à destruição ou à perda completa da vida fetal individual. De acordo com essa linha argumentativa, o

49 Reva siegel, "Dignity and the Abortion Debate", artigo apresentado no SELA (Seminário Latinoamericano de Teoria Constitucional e Política, jun./2009 (Assunção, Paraguai).

50 Tribunal Constitucional, 11.04.1985, S.T.C. 53/1985, 1985-49 BJC 515, para. 11 (b) (Espanha); Sentença C-355 (Colômbia), cf. nota 33, para. 8.1.; Ação de inconstitucionalidade 146/2007 e 147/2207 (México), cf. nota 31, voto do juiz Valls Hernández, p. 11, e voto do juiz Sánchez Cordero de Garcia Villegas, p. 15.189.

${ }^{51}$ Acórdão n. 75/2010, cf. nota 20, para. 11.4.11.

Revista Publicum

Rio de Janeiro, Número 2, 2016, p. 15-44.

http://www.e-publicacoes.uerj.br/index.php/publicum

DOI: $10.12957 /$ publicum.2016.25160 
benefício da criminalização - na medida em que efetivamente gere um efeito dissuasivo do aborto - poderia ser tido como dado, pela completa realização do valor constitucional de proteção da vida do nascituro. Ao contrário, os direitos da mulher - autonomia, privacidade, igualdade, saúde, e outros -, embora limitados pela criminalização, não seriam por esta extintos. A restrição aos direitos das mulheres às vezes é apresentada como uma limitação temporal, que duraria apenas os nove meses da gestação.

Esse raciocínio falha, todavia, novamente em medir o impacto da criminalização a partir da perspectiva das mulheres. Ainda que não exista uma correlação perfeita entre o caráter legal ou ilegal do aborto e seus riscos, está amplamente documentado que a morbidade e a mortalidade geradas pelo aborto tendem a ser altas nos países e regiões caracterizados por leis restritivas à medida, e muito baixas nos locais em que a regulação do aborto é mais liberal ${ }^{52}$. Os tribunais que justificam a legalização do aborto quando este se faz necessário para preservar a saúde da mulher, nos casos de grave má-formação fetal ou quando a gravidez produz uma violação ou provocará dificuldades sociais extremas, tendem a avaliar o impacto da criminalização tomando em conta aspectos que vão além do impacto puramente físico de se manter uma gestação. A intensidade do impacto sobre uma mulher pode ser de tal magnitude que, como expressou o Tribunal alemão, "[este direito] afirma sua validade com tanta urgência que o ordenamento jurídico não pode exigir que a mulher deva, em toda e qualquer circunstância, dar precedência ao direito do nascituro"53. Mais ainda, nas experiências das mulheres "reais", os impactos mais intensos das gestações não desejadas nem sempre coincidem com aquelas circunstâncias reconhecidas juridicamente como hipóteses legais de aborto. Essa evidência tem levado os legisladores - apoiados pelos tribunais - a repensar os regimes baseados em ressalvas, substituindo-os por outros, fundados em prazos e que reconhecem as mulheres como agentes morais encarregadas de realizar a ponderação dos bens em jogo. A instrumentalização do corpo da mulher, que existe, por exemplo, quando o direito exige a continuação de uma gravidez de risco para a integridade física da gestante, é considerada, atualmente, uma forma de tratamento desumano e degradante ${ }^{54}$.

Existe desacordo sobre quando ou em quais hipóteses seria contrário à dignidade da mulher proibir seu acesso ao aborto legal. A decisão alemã de 1975 baseia-se na ideia de que a responsabilidade da mulher quanto ao feto foi imposta pela própria natureza: "a

52 Sedgh et. Al., "Induced”, cf. nota 22, p. 625-626.

5339 BVergGE 1, cf. nota 7, para. 162; trad. em: Robert E. Jonas; John D. Gorby, p. 648.

54 L.M.R. v. Argentina, Communication n. 1068/2007, CCPR/C/101/D/168/2007 (Human Rights Comittee) (2011); K.L. v. Peru, Communication n. 1153/2003, U.N. Doc. CCPR/C/85/D/1153/2003 (Human Rights Committee) (2005). 
vida em desenvolvimento foi confiada, pela natureza, em primeiro lugar, à proteção da mãe. O principal objetivo do Estado na proteção à vida deve ser o de despertar e, se necessário, fortalecer o dever maternal de proteção, quando este se tenha perdido" ${ }^{55}$. De acordo com essa decisão, os impactos negativos que a gestação impõe sobre as mulheres não são atribuíveis ao direito, mas à própria natureza, e, como tal, não podem ser considerados uma restrição à dignidade das mulheres. A criminalização do aborto no caso de gestações normais não "impõe uma restrição severa [às mulheres]... já que [e.g., as limitações sobre sua autonomia] representam uma situação normal com a qual todos devem cooperar"56. Pode-se contrastar o raciocínio do tribunal alemão com o dos tribunais que não interpretam os sacrifícios da gestação através de estereótipos de gênero tradicionais. No caso Planned Parenthood vs. Casey, por exemplo, a Suprema Corte dos Estados Unidos reconheceu que, embora as mulheres sempre tenham suportado os sacrifícios inerentes à gestação, não se justifica que o Estado insista em impor "sua própria visão sobre o papel da mulher, pouco importando o quão dominante essa visão tenha sido no curso da nossa história e da nossa cultura. O destino da mulher deve ser moldado, em grande medida, pela sua própria concepção sobre quais são seus imperativos espirituais e qual é seu lugar na sociedade" 57 . O Tribunal Constitucional da Colômbia desenvolveu com maior profundidade as consequências do argumento da dignidade em relação ao aborto. O Tribunal entendeu que a criminalização do aborto é inconstitucional quando a gravidez for fruto de estupro, incesto, ou aplicação de alguma técnica de reprodução assistida sem o consentimento da mulher, por considerar que nesses casos a sanção penal violaria a dignidade da mulher grávida. O direito não pode exigir standards perfeccionistas de condutas ou comportamentos heroicos ${ }^{58}$. Não se pode forçar uma mulher a que assuma sacrifícios não usuais ou que renuncie a seu direito à integridade pessoal para proteger a vida do feto. Forçar uma mulher a manter uma gestação e dar nascimento a um feto inviável também constitui uma restrição excessiva aos seus direitos, equiparável à submissão a tratamento cruel, desumano e degradante, que afeta sua intangibilidade moral e, em última análise, sua dignidade humana ${ }^{59}$. Utilizando a linguagem da doutrina alemã sobre a inexigibilidade: isso seria simplesmente pedir demais.

5539 BVergGE 1, cf. nota 7, para. 154; trad. em: Robert E. Jonas; John D. Gorby, p. 644.

5639 BVergGE 1, cf. nota 7, para. 161; trad. em: Robert E. Jonas; John D. Gorby, p. 647.

57 Planned Parenthood of Southeastern Pa. v. Casey, 505 U.S. 833 (1992), at 852 (Suprema Corte norte-americana)

58 Sentença C-355/06, cf. nota 33, para.VI.10.1.

59 Sentença C-355/06, cf. nota 33, para.VI.10.1.

Revista Publicum

Rio de Janeiro, Número 2, 2016, p. 15-44.

http://www.e-publicacoes.uerj.br/index.php/publicum

DOI: $10.12957 /$ publicum.2016.25160 
Os argumentos baseados na dignidade mostraram-se decisivos no julgamento colombiano de 2006. A dignidade, como um princípio fundacional do sistema constitucional, foi definida de forma a incluir a ideia de autonomia para buscar o próprio projeto de vida, o que, por consequência, levou à conclusão de que não poderiam se atribuir papéis de gênero estigmatizantes às mulheres, tampouco provocar-lhes sofrimentos morais de forma deliberada ${ }^{60}$. De acordo com o Tribunal, uma proibição absoluta do aborto não respeita a dignidade das mulheres; as reduz a meros instrumentos reprodutivos e as priva de serem reconhecidas como sujeitos constitucionais. Ao definir os prejuízos da criminalização em termos de dignidade, a Corte colombiana deu pleno reconhecimento aos direitos reprodutivos das mulheres, entendendo-os como fundamentais para o sistema constitucional. A mulher grávida foi, desse modo, tratada como titular autônoma de direitos, cujo "consentimento... [reputa-se] essencial para a fundamental decisão, transformadora da vida de qualquer um, que é a de dar à luz a outra pessoa"61.

Na Colômbia, o aborto legal está restrito a três hipóteses. Basta examinar o ordenamento jurídico do país para dar-se conta de que o acesso lícito ao aborto é mais restrito do que na Alemanha. Apesar disso, em uma análise cuidadosa das decisões judiciais proferidas nos dois países, é possível perceber que a ideia de inexigibilidade [de conduta diversa da manutenção da gravidez] foi aplicada de maneira distinta da que se poderia imaginar pelas respectivas Cortes Constitucionais. A inexigibilidade no direito alemão ancorou-se em uma lógica de excepcionalidade: “a interrupção da gravidez só é legal naquelas circunstâncias excepcionais em que a continuação da mesma impuser uma carga à mulher tão severa e excepcional... que exceda os limites de auto-sacrifício exigíveis" ${ }^{2}$. O raciocínio da Corte colombiana, ao obrigar a que se reconhecessem no país causas permissivas do aborto, foi distinto. A Corte evitou usar a linguagem da excepcionalidade e amparou-se em uma aplicação um pouco mais - ainda que não plenamente - consistente do princípio da proporcionalidade. Declarou, assim, que o Direito Penal não deve ser utilizado para obrigar a mulher a prosseguir na gestação se houver meios idôneos menos restritivos aptos a proteger a vida do nascituro, e avaliou a proporcionalidade dos sacrifícios impostos aos direitos das mulheres grávidas. A Corte colombiana limitou o dispositivo de seu julgamento, porém, a três situações específicas, em que a criminalização do aborto geraria um ônus desproporcional às mulheres, pois

60 Sentença C-355/06, cf. nota 33, para.VI.8.1.

${ }^{61}$ Sentença C-355/06, cf. nota 33, para.VI.10.1.

6288 BVerfG 203, cf. nota 25, para. 201.

Revista Publicum

Rio de Janeiro, Número 2, 2016, p. 15-44.

http://www.e-publicacoes.uerj.br/index.php/publicum

DOI: $10.12957 /$ publicum.2016.25160 
superior a qualquer benefício à proteção à vida do nascituro. Em decorrência do enfoque dado à proporcionalidade, a Corte admitiu que possam existir outras situações em que a proibição do aborto mostre-se desproporcional, deixando aberta a possibilidade de o legislador ampliar as hipóteses de descriminalização da medida ${ }^{63}$.

\subsubsection{Uma questão de certeza: uma avaliação realista dos impactos} negativos e positivos da criminalização

O exame da proporcionalidade em sentido estrito exige que se determinem a confiabilidade e o grau de certeza das evidências empíricas em que baseados os juízos sobre os benefícios e os prejuízos gerados pela criminalização. Isso significa que os tribunais devem, por exemplo, indagar o quão confiáveis são os conhecimentos científicos invocados pelo legislador e ter cuidado quando a criminalização se fundamentar em evidências questionáveis. A incerteza sobre os efeitos futuros da lei, embora não impeça o legislador de promulgá-la, não exime a norma de sujeitar-se ao controle judicial de constitucionalidade. Em alguns casos, os danos da criminalização são refutados com o argumento de que os avanços da ciência médica tornaram desnecessária a interrupção da gravidez para salvar a vida ou resguardar a saúde da gestante, de modo que essas seriam situações suscitadas mais como ficção do que como realidade em favor do aborto. Em outras palavras, a criminalização raramente impediria a mulher de acessar serviços terapêuticos, que viabilizariam a continuidade da gestação em segurança. Alternativamente, mas ainda em defesa da criminalização do aborto, sustenta-se que a inefetividade da lei penal funciona como elemento de confirmação da proporcionalidade da medida. Destaca-se, nesse sentido, que a sanção penal dificilmente coloca em risco a saúde ou a vida da mulher, uma vez que os médicos desobedecem à regulamentação e realizam abortos terapêuticos mesmo diante da vedação penal. Ambos os argumentos ignoram evidências relevantes. Em muitos países, o efeito paralisante [chilling effect] da criminalização ultrapassa o âmbito de seu alcance normativo, e as mulheres têm rotineiramente negado o acesso aos serviços de aborto nas hipóteses admitidas em lei ${ }^{64}$. $\mathrm{E}$ mais: muitas mulheres não têm acesso a serviços médicos de última geração, que as permitiria cientificamente sobreviver a uma gestação de risco; a realidade de uma mulher sem acesso a serviços de saúde é a morte. Além disso, raramente se nota o mesmo ceticismo a respeito dos impactos positivos da criminalização, questionando-se se a

63 Sentença C-355/06, cf. nota 33, para.VI.11.

${ }^{64}$ A, B and C v. Ireland, Eur. Ct. H.R., [2010] E.C.H.R. 2032, para. 254.

Revista Publicum

Rio de Janeiro, Número 2, 2016, p. 15-44.

http://www.e-publicacoes.uerj.br/index.php/publicum

DOI: $10.12957 /$ publicum.2016.25160 
regulação penal tem êxito em dissuadir as mulheres a buscarem ou praticarem um aborto, ou se efetivamente fomenta uma cultura de respeito à vida humana e à dignidade.

O princípio da proporcionalidade conduz à consideração de argumentos substantivos que, muitas vezes, não são levados em conta, e obriga os juízes a avaliarem o impacto real da criminalização. Nas etapas finais de análise, os tribunais devem realizar a ponderação, perguntando-se se a proteção que a criminalização busca em favor da vida do nascituro justifica o sacrifício gerado às mulheres.

\section{Reconciliando deveres negativos e positivos}

A conciliação entre deveres positivos e deveres negativos é, possivelmente, um dos aspectos mais desafiadores da aplicação do princípio da proporcionalidade no controle judicial de constitucionalidade das leis sobre aborto. Alguns tribunais, como o colombiano em sua decisão de 2006, foram chamados a declarar se a criminalização infringe direitos das mulheres. O dever constitucional que se invoca como violado nesses casos é um dever negativo: o Estado teria a obrigação de abster-se de interferir nos direitos das mulheres à vida, à saúde, à autodeterminação, entre outros. A abstenção é, portanto, o atuar que se exige do Estado para atender a tais direitos.

Situação distinta se dá nos casos em que os tribunais são chamados a decidir se a criminalização viola a vida daquele que ainda está por nascer. A obrigação constitucional que se tem como supostamente violada nesses casos é positiva: de proteção da vida prénatal - e a violação alegada resulta da uma omissão ou deficiência na ação estatal. Nessas hipóteses, o Estado pode dar cumprimento à sua obrigação de diversas maneiras; a única coisa que se exige é que os meios adotados sejam suficientes para cumprir com a tarefa de proteção à vida do nascituro.

Essa diferença [entre o enfoque em direitos negativos ou positivos] é relevante na aplicação do princípio da proporcionalidade. É muito mais fácil para os tribunais declarar quando uma obrigação negativa foi violada do que determinar se foi atingido o mínimo de proteção exigido pela Constituição. Em consequência, tem-se observado uma tendência particularmente na jurisprudência contemporânea - a um maior grau de deferência ao legislador. Por exemplo, na decisão alemã de 1993, o Tribunal explicou que a Constituição identifica a proteção da vida do nascituro como uma meta, mas não define a forma com que essa meta deve ser atingida. Cabe ao legislador determinar essa forma e apenas "a 
proibição de proteção deficiente [estará]... sujeita ao controle de constitucionalidade" ${ }^{\prime \prime}$. Decisões recentes dos tribunais eslovaco e português enfatizaram, de maneira similar, a liberdade legislativa para decidir os meios e a intensidade de proteção à vida do nascituro, estabelecendo apenas um nível mínimo que essa proteção deveria atingir.

O desafio de aplicar uma análise da proporcionalidade nesses casos deriva do fato de que o legislador se encontra constrangido tanto por standards mínimos como máximos. A ação do Estado deve ser suficiente para proteger a vida do nascituro, mas não pode impor uma restrição excessiva aos direitos das mulheres. O Estado tem, ao mesmo tempo, que intervir e se abster. Por exemplo, o Tribunal eslavo, em sua decisão de 2007, advertiu que "o valor constitucional da vida do nascituro pode ser protegido, portanto, somente até o ponto em que essa proteção não interfira na essência da liberdade das mulheres e de seu direito à privacidade" ${ }^{66}$. Em seu julgado de 2012, o Tribunal português ponderou ambos os deveres de forma diferente, decidindo que "a função do imperativo de tutela [de direitos ou valores]... é substancialmente mais fraca do que a função dos direitos fundamentais como proibições de intervenção... [tanto] que a observância desse imperativo não legitima a invasão incondicional da esfera protegida por direitos fundamentais de outros sujeitos" ${ }^{\prime 67}$.

Vale recordar que não existe uma correlação necessária entre o nível invasivo de uma medida e o grau de proteção que ela promove. O Tribunal de Portugal, por exemplo, decidiu a questão do aborto principalmente a partir da premissa de que a descriminalização não necessariamente levaria a um grau menor de proteção à vida do nascituro. Entendeu-se que, ao contrário, o Estado parece poder cumprir plenamente com seu dever positivo de proteção à vida do nascituro tomando medidas para prevenir as gestações indesejadas - tais como, políticas de educação sexual e sobre métodos contraceptivos - e para apoiar a maternidade ${ }^{68}$.

\section{Conclusão}

Neste artigo, procurei demonstrar as oportunidades que o princípio da proporcionalidade oferece ao controle judicial das leis sobre aborto na condução para uma nova era de reformas progressistas na matéria. Como metodologia, a proporcionalidade exige que os

\footnotetext{
6588 BVerfG 203, cf. nota 25, para. 159.

66 PL. ÚS 12/01, cf. nota 43, para. II.A.2.4.

${ }^{67}$ Acórdão n. 75/2010, cf. nota 20, para. 11.4.11, 11.4.18.

68 Acórdão n. 75/2010, cf. nota 20, para. 11.4.18. 
juízes analisem temas que, muitas vezes, são deixados de lado ou são tomados em conta apenas de maneira abstrata e intuitiva. A proporcionalidade questiona, ainda, os verdadeiros efeitos da lei. Ao traçar as origens do aludido princípio na decisão constitucional alemã de 1975, pretendi expor suas profundas raízes nesse âmbito e os significativos avanços que os tribunais europeus e latino-americanos têm alcançado na compreensão e na aplicação do princípio nos casos envolvendo aborto. A mudança mais relevante consiste na transição de um modelo de ressalvas legais à interrupção da gestação, baseado na ideia de que apenas circunstâncias excepcionais justificam a não incidência da lei penal, para um modelo de prazos, fundado na ideia de que a norma penal deve ser empregada apenas se comprovadamente adequada, necessária e proporcional em sentido estrito para atingimento da finalidade de proteção à vida do nascituro.

\section{Referências Bibliográficas}

Antonio Bascuñán, "La Licitud del Aborto Consentido en el Derecho Chileno", Revista Derecho y Humanidades 10 (2004): 143-81.

Luís Roberto Barroso, "Bringing Abortion into Brazilian Public Debate: Legal Strategies for Anencephalic Pregnancy", em: Rebecca J. Cook, et. al., Abortion Law in Transnational Perspective: Cases and Controversies.

Reva Siegel, "The Right's Reasons: Constitutional Conflict and the Spread of Woman Proctective Antiabortion Argument", Duke Law Journal 57, n. 6 (2008), p. 1641-1692.

Robert Alexy, A Theory of Constitutional Rights, trad. Julian Rivers (Oxford: Oxford University Press, 2202).

Robert E. Jonas; John D. Gorby, "West German Abortion Decision: A Contrast to Roe v. Wade". John Marshall Journal of Practive and Procedure 9 (1976).

Verónica Undurraga, Aborto y Protección del que Está por Nacer en la Constitución Chilena, (Santiago: Legal Publishing Chile [Thomson Reuters], 2014).

Vanessa MacDonnel; Julia Hughes, "The German Abortion Decisions and the Protective Function in German and Canadian Constitutional Law". Osgoode Hall Law Journal 50.4 (2013), p. 999-1050.

Gilda Sedgh et. al., "Induced Abortion: Incidence and Trends Worlwilde from 1995 to 2008", Lancet 379, n. 9816 (2012): p. 625-632, doi: 10.1016/S0140-6736(11)61786-8 (Acesso em 30.06.2013)

David A. Grimes et. al., "Unsafe Abortion: The Preventable Pandemic", Lancet 368, n. 9550 (2006): p. 1908-19, doi: 10.1016/S0140-6736(06)69481-6 (acesso em 31.01.2013) 
Alan Guttmacher Institute, "Sharing Responsability: Women, Society and Abortion Worldwilde", Abortion, Reports (1999), http://guttmacher.org/pubs/sharing.pdf

Alan Guttmacher Institute, "Facts on Induced Abortion Worldwilde", Abortion, Fact Sheets (out./2009), http://www.guttmacher.org/pubs/tb_LAW.html;

Cicely Marston; John Cleland, "Relationships Between Contraception and Abortion: A Review of the Evidence", International Family Planning Perspectives 29, n. 01 (2013): p. 06-13.

Gilda Sedgh et. al., "Induced Abortion: Estimated Rates and Trends Worldwilde", Lancet 370, n. 9595 (2007): p. 1338-1345.

Marge Berer, "National Laws and Unsafe Abortion: The Parameters of Change", Reproductive Health Matters 12 (2004), p: 01-08.

Ronald D. Bachman, ed., "Romania: A Country Study", Washington, D.C., GPO for the U.S. Library Congress, 1989, http://countrystudies.us/romania/37.htm (acesso em 31.02.2013).

John Cleland et. Al., "Family Planning: The Unfinished Agenda", Lancet 368, n. 9549 (2006): p. 1810-1827.

Katharine T. Barlett, "Feminist Legal Method", Harvard Law Review 103, n. 4 (1990), p. 829-888.

Reva siegel, "Dignity and the Abortion Debate", artigo apresentado no SELA (Seminário Latino-americano de Teoria Constitucional e Política, jun./2009 (Assunção, Paraguai). 